\title{
Sex differences in settlement behaviour and condition of chiffchaffs Phylloscopus collybita at a wintering site in Portugal. Are females doing better?
}

\author{
Paulo Catry $\cdot$ Stuart Bearhop $\cdot$ Miguel Lecoq
}

Received: 26 October 2005 / Revised: 23 October 2006/ Accepted: 7 January 2007/ Published online: 6 March 2007

(C) Dt. Ornithologen-Gesellschaft e.V. 2007

\begin{abstract}
In passerine birds, males are generally larger and dominant over females. In line with the dominance theory, in all known differential migrant passerines, females migrate further than males. However, there are alternative explanations to the dominance hypothesis, including the specialisation hypothesis, predicting that females should do better than males in habitats and/or regions to which they are specially adapted, and where they predominate in numbers. Few studies have aimed at comparing the behaviour and condition of males and females wintering in locations largely dominated by female birds. We studied a partly nomadic species, the common chiffchaff Phylloscopus collybita, at a wintering site in Portugal. Most individuals caught at this site were transients. The only consistent and relatively powerful predictor of settlement behaviour was sex. Almost all the birds that settled in the study area were female, while there was an almost even sex ratio in the transient sample. Females had higher muscle and postjuvenile moult scores when first captured. In addition,
\end{abstract}

Communicated by F. Bairlein.

P. Catry $(\square)$

Unidade de Investigação em Eco-Etologia,

Instituto Superior de Psicologia Aplicada,

Rua Jardim do Tabaco 44, 1149-041 Lisboa, Portugal

e-mail: paulo.catry@netc.pt

S. Bearhop

Centre for Ecology and Conservation,

School of Biosciences, University of Exeter,

Cornwall Campus, Penryn TR10 9EZ, UK

M. Lecoq

Sociedade Portuguesa para o Estudo das Aves,

No. 53, $3^{\circ}$ Esq., 1100-618 Lisboa, Portugal there was a significant sex-based difference in mass trajectories, with females maintaining body mass and males losing body mass when settled at the study site. Results from this study suggest that the poor performance of males was either due to inferior male competitive ability in a region/habitat where females predominate and/or it resulted from the fact that males that reach these wintering grounds are of inferior individual quality.

Keywords Differential migration - Dominance . Sexual segregation

\section{Introduction}

Male and female individual birds are often found wintering predominantly in different geographical areas and/or in different habitats within the same region (e.g. Desrochers 1989; Sherry and Holmes 1996; Cristol et al. 1999; Catry et al. 2005a). There are several hypotheses accounting for such patterns of sexual segregation in the winter quarters, which can be grouped into two main broad themes (Catry et al. 2005a): (1) according to the social dominance hypothesis, sexual segregation arises from the fact that individuals of the subdominant sex are excluded from preferred habitats or regions by the despotic behaviour of dominant conspecifics (e.g. Gauthreaux Jr 1978; Greenberg 1986; Marra and Holmes 2001); and (2) the specialisation hypothesis, on the other hand, suggests that there are no broad competitive asymmetries between males and females (although such asymmetries are likely to occur locally), and that each sex favours the habitat or region where it can maximise its fitness; 
differences in the physiology, morphology and selective pressures on males and females result in differences in migratory behaviour and habitat selection, with a concomitant segregation in the winter quarters (e.g. Selander 1966; Morton 1990; Cristol et al. 1999).

Fitness consequences for males and females are predicted to be different under the two broad general scenarios. If dominance is the driving force promoting segregation, then individuals of the subdominant sex should suffer from negative fitness consequences as a result of their inferior competitive ability (Marra et al. 1998; Marra and Holmes 2001). Under the specialisation hypothesis, each sex should display a better performance in the habitats and regions to which it is better adapted (e.g. Cristol et al. 1999; Catry et al. 2005a). In passerine birds, males are generally larger and dominant over females. In line with the dominance theory, in all passerine species where differential migration has been conclusively documented, females winter further from the breeding quarters in comparison to males (Cristol et al. 1999). However, there are alternative explanations to the dominance hypothesis and these have been somewhat overlooked in previous studies. For example, comparisons between the behaviours of the sexes (and associated fitness consequences) in female-dominated wintering areas are rare (but see, for example: Morton 1990; Marra and Holmes 2001; Latta and Faarborg 2002).

In contrast to territorial species, relatively little is known about the ecology of migrant passerines that exhibit nomadic behaviour in their winter quarters (but see, for example: Senar et al. 1992; Rey 1995). As a wintering strategy, nomadism is poorly understood, but is possibly linked to ephemeral and unpredictable food resources. Since these kinds of resources are more difficult to monopolise, it might be expected that, in nomadic or non-territorial populations, the patterns and processes underlying segregation of different classes of individuals on the wintering grounds would be different to those populations where winter territoriality or site fidelity is important. However, these ideas remain untested.

The common chiffchaff Phylloscopus collybita is a small and almost exclusively insectivorous migratory Old World warbler (Sylviidae) and is particularly interesting because it has a flexible winter strategy, with the majority of individuals apparently showing nomadic behaviour in the winter quarters (Finlayson 1998; Catry et al. 2003). Chiffchaffs show sex-based differential migration, with males more commonly found at higher latitudes and females being more frequent in the southernmost wintering areas (Catry et al. 2005b).
We studied the settlement patterns and body condition of chiffchaffs at a site where the species is abundant during autumn and winter, in a region of the wintering range where females are more numerous than males (Catry et al. 2005b). According to the dominance model, we predict that males (which are $14 \%$ larger than females, in chiffchaffs) would: (1) have better or at least similar body condition to that of females, and (2) be more likely to become sedentary at this study site. This prediction of greater likelihood of males settling arises from observations in other species, where subordinates, mostly females and juveniles, have a greater tendency to behave as transients or floaters (e.g. Monaghan 1980; Davies and Houston 1981; Greenberg 1986; Piper and Wiley 1990; Senar et al. 1990, 1992). Within this framework, nomadism is generally seen as a more risk-prone life-style, resulting in lower survival (e.g. Rappole et al. 1989). According to the specialisation model, and in contrast with the statements above, we predict (3) that females would be in better condition than males, or at least be better able to maintain condition after becoming resident at this site, and (4) that males would have equal or greater propensity to behave nomadically, either because males forced to winter in female-biased habitats/regions are of inferior quality or because they would avoid staying for long in a suboptimal habitat.

\section{Methods}

Study site and population

The study site $\left(38^{\circ} 48^{\prime} \mathrm{N}, 8^{\circ} 55^{\prime} \mathrm{W}\right)$ was located some $15 \mathrm{~km} \mathrm{NE}$ (inland) of Lisbon, in coastal central southern Portugal. It consisted of a discrete 1-km line of low tamarisk Tamarix sp. trees, growing on a dyke that separates a belt of reedbeds and the river from pastures that cover the Tejo (Tagus) alluvial plains. Chiffchaffs inhabit the tall vegetation over the dyke, the reedbeds, ditches and fences, but avoid the open pastures that cover most of the area.

Chiffchaffs of the nominate subspecies ( $P$. c. collybita) are one of the most common avian winter visitors to Portugal. Most of these birds breed in the westernmost areas of middle Europe (in Ireland, UK, France and the Low Countries) and winter in Iberia and in North and sub-Saharan Africa (Cramp 1992). In our study area, chiffchaffs were present from early October to early March, being more common from October to late December. None of the individuals caught or heard in the field emitted the typical call of the summer breeding Iberian chiffchaff $P$. ibericus, and we believe 
those birds to have been absent from our study site in autumn and winter (see Catry et al. 2005b for more details).

\section{Trapping, biometrics and marking}

Chiffchaffs were trapped from dawn till early or mid-afternoon with the aid of mist-nets set to cross the tamarisk line at five fixed points. Capture sessions (1-day trapping) ranged from 11 October to 27 December in 1998 and from 5 to 26 November in 1999. A total of 16 capture sessions were organised (12 in 1998 and 4 in 1999) at approximately regular intervals and on no occasion were two successive trapping sessions less than 5 or more than 11 days apart. A total of 529 different individual chiffchaffs were trapped (403 in 1998 and 126 in 1999). In each capture session, a tape lure was placed near one of the nets to increase capture rates (Lecoq and Catry 2003). Twenty-six per cent of the birds captured and considered in this study were caught in a net with an active tape lure.

Every newly trapped bird was ringed and aged following the criteria described in Svensson (1992). Maximum wing chord was measured using a wing ruler and mass was taken using a Pesola spring balance. Subcutaneous fat reserves were assessed by visual inspection using a 9-point scale (Kaiser 1993) and pectoral muscle profiles were scored on a 3-point scale with reference to the prominence of the sternal keel and muscle shape following Gosler (1991). Pectoral muscle volume can be used as an indicator of overall protein reserves (Gosler 1991; Selman and Houston 1996) and may be a better indicator of condition than fat, reflecting long-term access to good quality diet instead of short-term strategic body mass regulation (Gosler 1991, 1996). All muscle and fat scoring were done by a single observer (M.L.).

In chiffchaffs, the extent of the post-juvenile moult is variable, with greater coverts, body and tail feathers being the main feather tracts involved. Tail feather moult is initiated last (Norman 1991), and replacing these feathers is likely to be more costly, due to their large size. The extent of chiffchaff tail moult is correlated to the extent of moult in other feather tracts (Jenni and Winkler 1994). Thus, tail feather moult was used as an index of the extent of post-juvenile moult. This variable was only measured in 1999.

All captured chiffchaffs were marked with colour rings. Birds captured in October and November 1998 were marked with a different "cohort" specific combination in each trapping session. If and when they were retrapped, these birds were fitted with a unique combination of colour rings enabling them to be identified as individuals. Birds caught in December
1998 and in 1999 were individually colour-marked when first caught. All birds were released at the ringing site, within a short distance $(<300 \mathrm{~m})$ from the trapping locations.

Each year, regular (approximately weekly) visits were made for the observation of colour-marked individuals until the end of March. Observation effort was standardised and constant in all visits, with the whole study area being visited twice in each visit. Visual recapture probability of birds present at the site was high ( 0.66 per fortnight, as estimated by applying capturerecapture models to re-sighting data), which results from small individual home ranges (Catry et al. 2003).

\section{Sexing}

Chiffchaffs are sexually dimorphic with respect to wing length (males larger) and there is little overlap between the sexes (Ticehurst 1938; Geen 1988). We used a maximum likelihood mixture model to separate the strongly bimodal distributions of wing lengths (see: MacDonald and Pitcher 1979; Catry et al. 2005b). We used program MIX3.1a (Ichthus Data Systems) to estimate parameters allowing the development of sexing criteria (with estimated $99 \%$ confidence levels) for our samples. Results are as follows: females (juvenile wing $\leq 57 \mathrm{~mm}$, adult $\leq 59 \mathrm{~mm}$ ), males (juvenile $\geq 60 \mathrm{~mm}$, adult $\geq 62 \mathrm{~mm}$ ). Only $12.5 \%$ of the birds could not be sexed on this basis.

Catching birds using a tape lure introduced a bias in sex ratios, because males are more readily attracted (Lecoq and Catry 2003). Hence, birds captured with tapes were not used to calculate the sex-ratio statistics presented in Results. However, they were used for all the other analyses involving settlement probability and body condition. Using only birds caught without tape lures in the analyses produced the same results (not shown).

Throughout this paper, duration of stay of colourmarked individuals was given by the number of days elapsing between first capture and last re-sighting. This is known to underestimate stopover durations (e.g. Schaub et al. 2001). However, given that visual recapture probabilities of chiffchaffs at our study site were very high (see above and Catry et al. 2003), it is likely that our measurements underestimate durations of stay by a small amount.

\section{Statistics}

Logistic regressions were used to model the probability of a bird behaving as a resident or a transient (see definitions in Results) as a response to the following 
explanatory variables: mark type, sex, age, fat score, muscle score, body mass, moult score and date of capture. The significance of the logistic regression models was assessed using likelihood-ratio tests, and the significance of individual variables in multivariate models using the Wald statistic (Norusis 1994). Means are presented with standard deviations, except where stated otherwise.

\section{Results}

\section{Settlement behaviour}

The large majority (70\%) of the birds individually colour-marked at first capture $(n=199)$ were never seen again, indicating that they stayed, at most, only a few days at the study site (see Catry et al. 2003 and Table 1 for more details). There were no cases of birds disappearing for 1 or 2 months and re-sighted later in the season, as would be the case if some individuals

Table 1 Frequency distributions of the number of common chiffchaffs Phylloscopus collybita staying different periods of time in the study area, as assessed by re-sightings of colourmarked individuals

\begin{tabular}{lll}
\hline $\begin{array}{l}\text { No. of weeks } \\
\text { of stay }\end{array}$ & $\begin{array}{l}\text { Frequency } \\
\text { observed }\end{array}$ & $\begin{array}{l}\text { Frequency } \\
\text { expected }\end{array}$ \\
\hline 0 & 139 & 76.2 \\
1 & 15 & 47.0 \\
2 & 11 & 29.0 \\
3 & 6 & 17.9 \\
4 & 4 & 11.1 \\
5 & 4 & 6.8 \\
6 & 4 & 4.2 \\
7 & 1 & 1.6 \\
8 & 1 & 1.0 \\
9 & 1 & 0.6 \\
10 & 0 & 0.4 \\
11 & 2 & 0.2 \\
12 & 1 & 0.1 \\
13 & 1 & 0.1 \\
14 & 5 & 0.1 \\
15 & 1 & 0 \\
16 & 2 & 0 \\
17 & 0 & 0 \\
18 & 1 & 0 \\
19 & 0 & 0 \\
20 & 0 & 0 \\
21 & 0 & 0 \\
\hline
\end{tabular}

Time of stay is the number of weeks from first to last capture of individually colour-ringed birds. Individuals staying 0 weeks were only seen when captured and marked. Individuals staying 1 week were those staying between 1 and 7 days, and so on. Expected values were calculated from a geometric distribution, which would be expected if departure probability was independent of duration of stay. The difference between expected and observed is highly significant (see text) were temporarily using this site on passage in autumn and again in late winter or spring.

If the probability of an individual departing the study site was independent of the time it had already been present, the frequencies of the duration of stay should follow a geometric distribution (Senar et al. 1992). In Table 1, we present the observed and expected frequencies for 1-week classes of duration of stay. There was a strong deviation from the random departure-time model (Kolmogorov-Smirnov $D=$ 0.611, $n=199, P<0.0001$ ). This resulted from both larger numbers of birds departing earlier than expected and larger numbers of birds remaining for longer periods ( $>2$ months) than expected. Following Senar et al. (1992), individuals belonging to the larger-thanexpected group of birds caught and seen only once were categorised as transients. All other birds were categorised as residents.

\section{Sex differences in settlement probability}

For the following analyses, both individually colourringed and cohort-ringed birds (that could only be identified after first recapture in the mist-nets) were included. Therefore, we incorporated the type of mark used as a random factor in the predictive models, to control for differences in recapture probabilities. The main results remain unchanged when the analyses are conducted using only the smaller group of birds individually colour-ringed at first capture and using only recaptures by re-sighting.

Only sex affected the probability of a bird behaving as a transient (Table 2). Females were more likely to settle at the study site than males, with a highly significant association in both autumn/winters (logistic

Table 2 Results from a stepwise backward multiple logistic regression to assess the influence of measured variables on the probability of a bird being recaptured (retrapped or re-sighted) in the study areas

\begin{tabular}{llll}
\hline Variable & $\begin{array}{l}\beta \text {-regression } \\
\text { coefficient } \pm \mathrm{SE}\end{array}$ & Wald & $P$-value \\
\hline Mark type & $1.79 \pm 0.30$ & 36.1 & $<0.0001$ \\
Sex & $2.43 \pm 0.40$ & 36.0 & $<0.0001$ \\
Age & Excluded & & n.s. \\
Fat score & Excluded & & n.s. \\
Muscle score & Excluded & & n.s. \\
Body mass & Excluded & & n.s. \\
Moult & Excluded & n.s. \\
Date & Excluded & n.s. \\
\hline
\end{tabular}

The overall model was highly significant $\left(G^{2}{ }_{4}=91.4, n=460\right.$, $P<0.0001)$. Females were more likely to settle in the study area; individually colour-ringed birds were more likely to be recaptured. n.s. Not significant 
regression: sex effect $1998-1999, G^{2}{ }_{1}=23.7, n=345$, $P<0.0001$; sex effect 1999-2000, $G_{1}^{2}=21.8, n=118$, $P<0.0001)$. Age, fat and muscle scores did not affect settlement probability (Table 2). In the case of birds caught without tape lures, the sex ratio was heavily biased towards females among residents, with males representing only $6.4 \%$ of this sample ( $n=62$, binomial test $P<0.001)$. However, amongst transients $(n=277)$, the sex ratio was more even, with $44 \%$ males (see also Fig. 1).

Date had no effect on the settlement probability (Table 2), meaning that there was not a defined period of migration, with many transients, followed by a period of settlement.
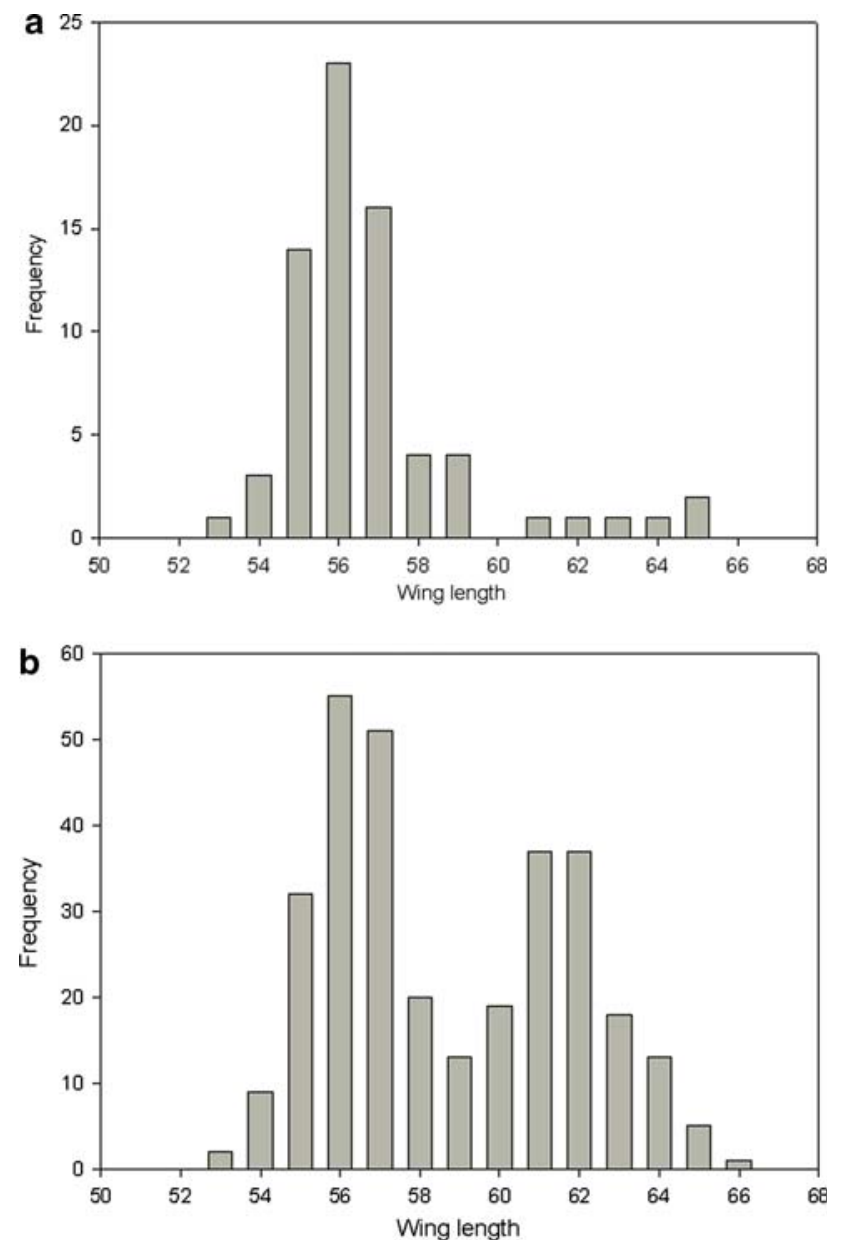

Fig. 1 Chiffchaff wing-length frequency including only a birds that settled at the study site: "residents", and b birds that were captured only once and never seen again: "transients". Note the clear bimodal pattern of the distributions, resulting from the pronounced sexual size dimorphism in this species. There is a highly significant difference in the sex ratio of the resident and transient populations, with very few males settling down at the study site (see text)
There was no difference between males and females in the duration of stay for residents (median duration of stay of males $=28$ days, $n=8$; females $=18$ days, $n=71$, Mann-Whitney $U=254, P=0.6$ ). The very small number of male recaptures, particularly after the necessary removal of the initial capture and ringing event in order to minimise any biases related to differences between capture and recapture techniques, prevented us from modelling capture-recapture probability in relation to sex using established techniques to infer stopover duration (e.g. Schaub et al. 2001).

Other differences between the sexes

At first capture, muscle scores were higher in females $(2.42 \pm 0.50, n=269)$ than in males $(2.24 \pm 0.47$, $n=191$ ), a highly significant difference in both years of study (Mann-Whitney $U, 1998, U=12,207, P=0.003$; $1999, U=1,248, P=0.004)$, but no difference was found in fat scores (males $=2.05 \pm 1.01$, females $=$ $2.00 \pm 0.98, \quad$ Mann-Whitney $U=25,324, \quad P=0.8$ ). Muscle scores significantly affected body mass $(F=$ $10.8, P=0.001)$ in a General Linear Model that accounted for the variation in mass caused by sex, size and fat score, confirming the utility of muscle-score measurements (see also Gosler et al. 1998). In addition, the post-juvenile tail moults of females captured at the study site were more advanced than males (MannWhitney $U=1,883, P=0.04$, Table 3).

After accounting for the effect of tape lures, there was no influence of date on the probability of catching males or females (logistic regression, date $\beta \pm \mathrm{SE}=$ $-0.01 \pm 0.01, n=461$, Wald $=1.7, P=0.2$ ), indicating that timing and pattern of seasonal occurrence at the study site was similar for both sexes. In cases where birds settled at the study site and were recaptured, males lost mass between first and last capture (mean difference $=-0.46 \pm 0.47 \mathrm{~g}, n=5$ ), while females did not $(+0.21 \pm 0.56 \mathrm{~g}, n=31)$, a significant difference between the sexes (ANOVA $F_{1,34}=1.93, P=0.02$ ). This result remains significant even when daily fattening rates (mass change divided by the number of days elapsed between weightings) are substituted for overall mass change (males $=-0.06 \pm 0.08 \mathrm{~g} \mathrm{day}^{-1}$,

Table 3 Observed frequency of juvenile chiffchaffs with different numbers of tail feathers moulted

\begin{tabular}{llllllllllllll}
\hline & \multicolumn{10}{c}{ Number of tail feathers moulted } \\
\cline { 2 - 7 } & 0 & 1 & 2 & 3 & 4 & 5 & 6 & 7 & 8 & 9 & 10 & 11 & 12 \\
\hline Males & 23 & 3 & 23 & 2 & 3 & 2 & & & & & & 1 & 2 \\
Females & 18 & 2 & 40 & 7 & 2 & 1 & 3 & & 1 & 1 & & & 4 \\
\hline
\end{tabular}


females $=0.02 \pm 0.05 \mathrm{~g} \mathrm{day}^{-1}, \quad$ ANOVA $\quad F_{1,34}=8.4$, $P=0.007)$.

Behaviour at the study site

The spatial behaviour of chiffchaffs at this study site has been described by Catry et al. (2003). Throughout autumn and winter, chiffchaffs foraged mostly in loose flocks (occasionally singly) displaying little or no interactions between flock members. There was no evidence of territorial behaviour, although some individuals had very small home ranges; such individuals often joined foraging flocks. Song was never heard, although it occasionally occurs at other wintering sites in Portugal.

\section{Discussion}

This study documents a pronounced sex difference in the behaviour of partly nomadic chiffchaffs at a wintering site in Portugal, with males having a greater tendency to behave as transients and females being more likely to become temporarily sedentary. Settlement at the study site most likely had profound consequences for males, since the few that did settle (unlike females) lost body mass during their stay. When first trapped, females were in better body condition than males. We know of few if any other studies describing similar patterns in wintering passerines.

It could be argued that our study site might be more of staging area rather than a classical wintering site. If this was the case, the following predictions could be made: (1) the sex ratio of transients should be more female-biased than the sex ratio of residents, because female chiffchaffs winter further south than males; (2) transients should have larger fat scores than residents as they would have to be carrying enough resources to move to the next staging or wintering area; (3) more transients should be caught in autumn and more residents in winter; and (4) individuals should accumulate fat while stopping over. None of these predictions are supported by the data, favouring the alternative view that birds visiting the study site for very short periods are not passing migrants, but rather nomads or floaters that have much larger individual wintering ranges (see also: Finlayson 1998; Catry et al. 2003). Nomadic behaviour at the winter quarters has been described for at least one other species of the same genus as the chiffchaff, namely the willow warbler $P$. trochilus (Rabøl 1987; Salewski et al. 2002). Despite this evidence for nomadic behaviour, some individual chiffchaffs settled down and remained at the study site for part of the winter. Such birds had very small home ranges, each one of them using only a small section of the study area (Catry et al. 2003).

The habitat at the study site is not marginal or atypical for the species. Wetland margins are the most favoured habitats for chiffchaffs throughout the entire European wintering range (e.g. Bland 1986; Olioso 1991; Finlayson 1998). The large number of birds trapped for this study also supports this idea.

It should also be stressed that we found no differences between the sexes in the timing of first capture at our study site and hence differences in the behaviour and condition of males and females cannot be attributed to possible confounding seasonal effects acting differently in male and female birds.

\section{Dominance or specialisation?}

Many studies have found dominant birds (often, but not exclusively, the larger and more experienced adult males) to be more sedentary in the winter quarters. Subordinates (often females and juveniles) have a greater tendency to behave as transients or floaters (e.g. Monaghan 1980; Davies and Houston 1981; Greenberg 1986; Piper and Wiley 1990; Senar et al. 1990, 1992), which can be a more risk-prone strategy, resulting in lower survival (e.g. Rappole et al. 1989). Dominance is often found to be a strong predictor of winter body condition as well, which could be mediated by better access and control of resources by more sedentary birds (Piper and Wiley 1990; Carrascal et al. 1998; Gosler and Carruthers 1999). If females were the dominant sex in chiffchaffs, the patterns described in this study could be attributed to females preventing males from settling in our study site. The reality, however, is that males are the larger sex, weighing, on average, $14 \%$ more than females. Furthermore, male birds often are naturally more aggressive, resulting in greater dominance in the non-breeding season (Piper 1997). Hence, it would be difficult to imagine that female chiffchaffs could, on average, be dominant over males. In any case, aggressive interactions amongst chiffchaffs at our study site were almost never recorded and birds often moved in loose flocks. Social dominance interactions are therefore unlikely to have created these patterns.

The only consistent and relatively powerful predictor of local settlement was sex. Two general possibilities must be considered to explain the reported pattern. Either male chiffchaffs wintering in southern Portugal have a greater propensity to be nomadic and permanently on the move, or they winter (being sedentary or not) mostly in different habitats. These two 
possibilities will have to be properly evaluated by further and detailed studies in different habitats. It is interesting to note, however, that a study carried out in a very different habitat (dry land covered mostly by scrub and orchards) $200 \mathrm{~km}$ to the south of our site, found an even more female-biased sex ratio than we did (Thomas 1994).

The patterns revealed by the data from this study are more consistent with the specialisation hypothesis, since they upheld predictions 3 (better female body condition) and 4 (lower local settlement rates of males), as detailed in the Introduction. If males are more poorly adapted to the local conditions, they should have a greater likelihood of moving away and, if staying, suffer from degradation in body condition. However, our data cannot reject the hypothesis that dominant males exclude females from more northerly wintering sites and that only low-quality/dominance males reach our study area (see below).

Low-quality males in the South?

Chiffchaffs are differential distance migrants and most males of the Western European populations apparently winter north of our study area (Catry et al. 2005b). One interesting possibility is that males reaching the study site could be relatively low quality (the better males remaining further north, or in different habitats), an idea that gets support from evidence related to their moult scores. Note that post-juvenile moult takes place before autumn migration and was complete by the time the birds reached our study area. The extent of postjuvenile moult has been regarded as an indicator of condition or quality, because more nutritionally constrained individuals are thought to renew a smaller number of feathers (Gosler 1991). Juvenile males caught by us had renewed fewer tail feathers than juvenile females, suggesting that they were, on average, of lower individual quality (alternatively, there might be a yet undescribed difference in post-juvenile moult strategies of male and female chiffchaffs).

Muscle-score data also concur with the hypothesis of low-quality males, as scores were consistently higher in female birds, irrespective of their residency status. Note that for mostly nomadic birds, muscle scores are unlikely to reflect local conditions, since muscle reserves, unlike fat, change slowly, not on a daily basis (Gosler and Carruthers 1999). Muscle scores tend to be higher in socially dominant classes, or in better habitats (Gosler 1996; Carrascal et al. 1998; Catry et al. 2004), and high muscle scores are thought of as an indication of good physical condition (Gosler 1991, 1996). Hence, the low muscle scores of males caught at our study site suggest either that males were of lower quality than females, or that they were paying a price for wintering in a suboptimal habitat or region. The fact that males lost mass at the study site, while females maintained it, can also be seen as evidence for the low-quality male hypothesis, although it would also be consistent with the view that males (irrespective of their individual quality) lost mass because they are not well adapted to the predominant habitat at the study site.

It should be noted that the estimated proportion of males in chiffchaff samples wintering in our study region is around $33 \%$, and many males reach areas further south (Catry et al. 2005b). Knowing that the species is extremely abundant in this region, it is clear that the extreme scenario where only a few handicapped males could have managed to reach our study site is an unlikely one. Furthermore, many females winter in more northerly regions. In other words, the advantage of females reported here is not the result of comparing a few "top" females in this particular flyway with the worst "bottom" males. It is likely that other factors, beyond a possible latitudinal segregation by individual quality, contribute to underlie the patterns reported here.

\section{Conclusion}

The results from this study demonstrate that, in a differential migrant, females can apparently be better adapted than males to a particular wintering site where they predominate in numbers. The apparent disadvantage of males can either result from their low individual quality, or from a poor adaptation to general environmental conditions (including the presence of superior competitors) in female-dominated habitats. More study is needed, at different habitats and geographical locations, to discriminate between these two possibilities. In any case, given that the two sexes do apparently have different winter distributions and strategies, habitat availability during this period could clearly influence population dynamics in a site-dependent manner (Rodenhouse et al. 1997).

\section{Zusammenfassung}

Geschlechtsspezifische Unterschiede in Überwinterungs-Verhalten und Körperverfassung von Zilpzalpen (Phylloscopus collybita) in einem Überwinterungsgebiet in Portugal

Bei Singvögeln sind die Männchen für gewöhnlich größer und gegenüber den Weibchen dominant. Über- 
einstimmend mit der Dominanztheorie ziehen die Weibchen aller Singvögel mit differenziellem Zugmuster weiter als die Männchen. Dennoch gibt es, alternativ zur Dominanzhypothese, andere Erklärungsmodelle wie die Spezialisierungshypothese, die voraussagt, dass Weibchen in den Habitaten und/oder Regionen, an die sie speziell angepasst sind, besser abschneiden als die Männchen und dort zahlenmäßig dominieren. Wenige Arbeiten zielten bisher auf den Vergleich von Verhalten und Kondition von Männchen und Weibchen in ausgesprochen von Weibchen dominierten Winterquartieren. Wir haben eine teilziehende Vogelart, den Zilpzalp (Phylloscopus collybita) in einem Winterquartier in Portugal untersucht. Bei den meisten Individuen, die in diesem Gebiet gefangen wurden, handelte es sich um Durchzügler. Der einzig konsistente und relativ starke Vorhersage-Faktor, ob ein Individuum dort überwinterte oder nicht, war sein Geschlecht. Beinahe alle Vögel, die in der Untersuchungsfläche überwinterten waren Weibchen, während das Geschlechterverhältnis in der Stichprobe der Durchzügler beinahe ausgeglichen war. Beim Erstfang hatten Weibchen höhere Muskelwerte und waren in der Jugendmauser weiter fortgeschritten. Zusätzlich fand sich ein signifikant geschlechtsspezifischer Unterschied in der Körpermasseentwicklung, wobei im Gebiet überwinternde Weibchen ihr Körpergewicht hielten und Männchen an Köpermasse verloren. Die Ergebnisse dieser Studie legen nahe, dass die schlechte Körperverfassung der Männchen entweder von der geringeren Wettbewerbsfähigkeit der Männchen in einem von Weibchen dominierten Gebiet/Habitat herrührte und/ oder von der Tatsache, dass Männchen, die in diese Winterquartiere gelangen, eine geringere individuelle Fitness aufweisen.

Acknowledgments Ana Campos, Inês Catry, Teresa Catry and Teresa Martins were of great help during fieldwork. Will Cresswell gave much needed support at various stages of manuscript preparation. Richard T. Holmes and two anonymous referees made useful comments on a previous draft. This study was financed by Fundação para a Ciência e Tecnologia (FCT-Portugal) as part of the Programa Plurianual (UI\&D 331/94) and by research grants Praxis XXI BPD/16304/98 and BPD/11631/02. S. Bearhop was funded by a NERC Postdoctoral Fellowship.

\section{References}

Bland RL (1986) Chiffchaff. In: Lack P (ed) The atlas of wintering birds in Britain and Ireland. Poyser, Calton, pp 334-335

Carrascal LM, Senar JC, Mozetich I, Uribe F, Domenech J (1998) Interactions among environmental stress, body condition, nutritional status, and dominance in great tits. Auk 115:727-738
Catry P, Catry I, Catry T, Martins T (2003) Within and betweenyear winter-site fidelity of chiffchaffs Phylloscopus collybita. Ardea 91:213-220

Catry P, Campos A, Almada V, Cresswell W (2004) Winter segregation of migrant European robins Erithacus rubecula in relation to sex, age and size. J Avian Biol 35:204-209

Catry P, Phillips R, Croxall JP (2005a) Sexual segregation in birds: patterns, processes and implications for conservation. In: Ruckstuhl KE, Neuhaus P (eds) Sexual segregation in vertebrates: ecology of the two sexes. Cambridge University Press, Cambridge

Catry P, Lecoq M, Araújo A, Conway G, Felgueiras M, King JMB, Rumsey S, Salima H, Tenreiro P (2005b) Differential migration of chiffchaffs Phylloscopus collybita and $P$. ibericus in Europe and Africa. J Avian Biol 36:184-190

Cramp S (ed) (1992) The birds of the Western Palearctic, vol 6. Oxford University Press, Oxford

Cristol DA, Baker MB, Carbone C (1999) Differential migration revisited. Latitudinal segregation by age and sex class. Curr Ornithol 15:33-88

Davies NB, Houston AI (1981) Owners and satellites: the economics of territory defence in the pied wagtail Motacilla alba. J Anim Ecol 50:157-180

Desrochers A (1989) Sex, dominance and microhabitat use in wintering black-capped chickadees: a field experiment. Ecology 70:636-645

Finlayson JC (1998) The role of the Iberian Peninsula in the Palaearctic-African migration system: ecological, evolutionary, geographical and historical considerations at varying spatial and temporal scales. In: Costa LT, Costa H, Araújo M, Silva MA (eds) Simpósio sobre Aves Migradoras na Península Ibérica. SPEA, Lisboa \& Universidade de Évora, pp 2-32

Gauthreaux SA Jr (1978) The ecological significance of behavioural dominance. Perspect Ethol 3:17-54

Geen RG (1988) The autumn migration of chiffchaffs at an inland site in south-east England. Ring Migr 9:65-67

Gosler AG (1991) On the use of greater covert moult and pectoral muscle as measures of condition in passerines with data for the great tit Parus major. Bird Study 38:1-9

Gosler AG (1996) Environmental and social determinants of winter fat storage in the great tit Parus major. J Anim Ecol 65:1-17

Gosler AG, Carruthers T (1999) Body reserves and social dominance in the great tit Parus major in relation to winter weather in Southwest Ireland. J Avian Biol 30:447-459

Gosler AG, Greenwood JJD, Baker JK, Davidson NC (1998) The field determination of body size and condition in passerines: a report to the British Ringing Committee. Bird Study 45:92-103

Greenberg R (1986) Competition in migrant birds in the nonbreeding season. Curr Ornithol 3:281-307

Jenni L, Winkler R (1994) Moult and ageing of European passerines. Academic, London

Kaiser A (1993) A new multi-category classification of subcutaneous fat deposits of songbirds. J Field Ornithol 64:246-255

Latta SC, Faarborg J (2002) Demographic and population responses of Cape May warbler wintering in multiple habitats. Ecology 83:2502-2515

Lecoq M, Catry P (2003) Diurnal tape-luring of wintering chiffchaffs results in samples with biased sex ratios. J Field Ornithol 74:230-232

MacDonald PDM, Pitcher TJ (1979) Age-groups from sizefrequency data: a versatile and efficient method of analysing distribution mixtures. J Fish Res Board Can 36:987-1001 
Marra PP, Holmes RT (2001) Consequences of dominancemediated habitat segregation in American redstarts during the nonbreeding season. Auk 118:92-104

Marra PP, Hobson KA, Holmes RT (1998) Linking winter and summer events in a migratory bird by using stable carbon isotopes. Science 282:1884-1886

Monaghan P (1980) Dominance and dispersal between feeding sites in the herring gull (Larus argentatus). Anim Behav 28:521-527

Morton ES (1990) Habitat segregation by sex in the hooded warbler: experiments on proximate causation and discussion of its evolution. Am Nat 135:319-333

Norman SC (1991) Post-juvenile moult in relation to dispersal and migration in the chiffchaff Phylloscopus collybita. Ring Migr 12:80-85

Norusis MJ (1994) SPSS advanced statistics. SPSS, Chicago

Olioso G (1991) Pouillot véloce. In: Yetman-Berthelot D (ed) Atlas des Oiseaux de France en Hiver. Société Ornithologique de France, Paris, pp 422-423

Piper WH (1997) Social dominance in birds: early finding and new horizons. Curr Ornithol 14:125-187

Piper WH, Wiley RH (1990) Correlates of range size in wintering white-throated sparrows Zonotrichia albicollis. Anim Behav 40:545-552

Rabøl J (1987) Coexistence and competition between overwintering willow warblers Phylloscopus trochilus and local warblers at Lake Naivasha, Kenya. Ornis Scand 18:101-121

Rappole JH, Ramos MA, Winker K (1989) Wintering wood thrush movements and mortality in southern Veracruz. Auk 106:402-410

Rey PJ (1995) Spatio-temporal variation in fruit abundance and frugivorous bird abundance in olive orchards. Ecology 76:1625-1635
Rodenhouse NL, Sherry TW, Holmes RT (1997) Site-dependent regulation of population size: a new synthesis. Ecology 78:2025-2042

Salewski V, Bairlein F, Leisler B (2002) Different wintering strategies of two Palearctic migrants in West Africa-a consequence of foraging strategies. Ibis 144:85-93

Schaub M, Pradel R, Jenni L, Lebreton JD (2001) Migrating birds stop over longer than usually thought: an improved capture-recapture analysis. Ecology 82:852-859

Selander RK (1966) Sexual dimorphism and differential niche utilization in birds. Condor 68:113-151

Selman RG, Houston DC (1996) A technique for measuring lean pectoral muscle mass in live small birds. Ibis 138:348-350

Senar JC, Copete JL, Metcalfe NB (1990) Dominance relationships between resident and transient wintering siskins. Ornis Scand 21:129-132

Senar JC, Burton PJK, Metcalfe NB (1992) Variation in the nomadic tendency of a wintering finch Carduelis spinus and its relationship with body condition. Ornis Scand 23:63-72

Sherry TW, Holmes RT (1996) Winter habitat quality, population limitation and conservation of Neotropical-Nearctic migrant birds. Ecology 77:36-48

Svensson L (1992) Identification guide to European passerines. Lars Svensson, Stockholm

Thomas R (1994) Sexual dimorphism and migration of chiffchaff subspecies in Southern Portugal. A Rocha Observatory Report, Portimão, pp 34-41

Ticehurst CB (1938) A systematic review of the genus Phylloscopus. British Museum, London 